\title{
Diplomacy at Crossroads: Challenges of Nigeria's Foreign Service
}

\author{
Emmanuel I. Umeonyirioha* \\ School of International Relations/Research School for South East Asian Studies, \\ Xiamen University, Xiamen, Fujian Province, China \\ *Corresponding author: lordibmbomb@yahoo.com
}

Received November 04, 2019; Revised December 10, 2019; Accepted December 25, 2019

\begin{abstract}
This paper surveys the myriad challenges that confront and frustrate the fulfillment of Nigeria's diplomatic visions and missions overseas. There is a wide-spread understanding and acceptance that Nigeria's foreign and diplomatic missions operate below expectation. This is more so when comparisonis made between Nigeria's diplomatic performance and those of the developed and well-ordered societies of the world. Nigeria's foreign policy through its missions abroad is expected to improve the lots of its citizens living overseas, bring the country's national and domestic interests to the stage of actualization, and project the country's image as good before the comity of nations etc. To these expectations, the Nigerian state and its diplomacy leave much to be desired. Among other explanations for this failure of diplomacy are infiltration of the diplomatic profession by non-careerists who by their unprofessionalism, have shown to be foreigners in the foreign service; wanton corruption by the political class which frustrates foreign services; inadequacy of financial resources needed for role performance leading to embarrassments and difficulty in the timely payments of bills etc. The paper concludes that it is both imperative and compelling for the executive government of Nigeria to wake up to these challenges as a matter of urgency, if Nigeria must play an active role that befits its status in international affairs.
\end{abstract}

Keywords: diplomacy, foreign mission, diplomats, challenges

Cite This Article: Emmanuel I. Umeonyirioha, "Diplomacy at Crossroads: Challenges of Nigeria’s Foreign Service.” World Journal of Social Sciences and Humanities, vol. 6, no. 1 (2020): 8-14. doi: 10.12691/wjssh-6-1-2.

\section{Introduction}

Indisputably, there exists a nexus between National Interest, Foreign Policy and Diplomacy. A balanced and comprehensive conceptual discourse on diplomacy must as a matter of fact, take off from this premise. It goes without contestation that every state acting like a player on the international stage, has a number of goals and aims it deems as core values, and which it pursues and desires to actualize. These goals otherwise known as national interests inform what plans and decisions that must be taken by the government of the day, as a vehicle that will necessarily transport and transform the articulated goals and interests into living and concrete realities. The set of decisions and policies consciously designed by the government to catapult its state's national interests to its desired point of destination is known as foreign policy. However, irrespective of how beautiful a country's foreign policy may sound and appear to be, it sure remains a mirage or a forlorn hope if it is not drawn down to the level of implementation. It is one thing to plan (or have a policy), it is another thing to have the plan or policy implemented, for without implementation, any foreign policy remains dead on arrival. The implementation of foreign policy defines and qualifies diplomacy and diplomatic mission. Saliu [1] buttresses this further when he notes that diplomatic mission occupies a vital position in the conduct of a country's foreign policy. Equally, Diplomacy is an instrument of foreign policy, an essential, subtle method by which states fulfill their foreign policies. Besides projecting and meeting a country's domestic and national interests, the goal of diplomacy is to maintain a cordial relationship with foreign nations as well as build a good image for the nation [2]. Admitting that diplomacy is an essential foreign policy undertaking, and a key component of a nation's supremacy, Berridge underlines its major aim as making it possible for states to achieve the goals of their foreign policies..." [3]. Undeniably, diplomatic missions are extremely important in the world in projecting the power and influence of a country. They facilitate, as Berridge had said, the realization of the national objectives of modern states, and "cultivate the friendship of notable actors especially the benevolence of crucial actors in the world" [1]. If these, and many more are true of diplomacy, and what diplomacy through a country's diplomatic missions do for a country, then the question is, do these apply to Nigeria and its diplomatic missions abroad? Taking the position that Nigeria's diplomatic and Foreign Service punches below the target, this paper concentrates on the issues that haunt Nigeria's diplomatic practice, and debilitates its performance. Over the years, Nigerian scholars within the field of Political 
Science and International Relations have paid a great deal of attention to the foreign policy of Nigeria, while ignoring or paying little attention to its diplomats and diplomatic missions. In an attempt to partly address this regrettable neglect in Nigeria's diplomatic discourse, this paper discusses the problems and challenges of Nigeria's diplomatic missions.

\section{A Brief Historical Survey of Nigeria's Foreign Service}

The evolution of Nigeria's Foreign Service began in 1957 when the first recruitment was made into the service. Those recruited that year, about twelve in number, formed the foundation staff of the Nigerian Foreign Service, as ground-preparation for the take-off of Nigeria's diplomatic practice as well as getting the nation ready for its initial foreign representation after independence [4,5,6]. It should be recalled that Nigeria at this date was still under the colonial authority of Britain; therefore, the recruitment was conducted by the erstwhile colonial overlords. The pioneer staffs were recruited from mostly legal and teaching professions [1]. Another round of recruitment into the Foreign Service was conducted in 1958 and 1959. Like the first twelve, these officers recruited subsequently were sent to British university for one year training. The people who served as pioneer staff in the Foreign Service department were Omotayo Ogunsulire; Philip Asiodu; Dickson Igwe; Leslie Harriman; Aminu Sanusi; Adedokun Haastrup; Chike Chukwurah; Chukwuemeka Ifeagwu; Soji Williams; John Mamman Garba; Olujimi Jolaoso; Olumide Omololu; John Ukegbu; Olusola Sanu; Ignatius Olisaemeka; Victor Adegoroye; Edward Enahoro; Sule Kolo and George Dove-Edwin [7]. Owing to the overriding influence and powers of colonialism, these recruits were only taught British diplomacy, and were exposed to the British diplomatic missions across the world. It is noteworthy that at this time, no organ or department was assigned the responsibility of conducting Nigerian foreign policy. As would be expected, Britain was responsible for conducting the foreign policies of all her colonies including Nigeria. The Department of External Affairs and Commonwealth Relations was however, later formed in the office of the Prime Minister, which saw off the flagship of the foreign policy process with the Prime Minister's Secretary stepping in lead the newly formed department. This remained the situation until the attainment of independence in 1960. However, the attainment of independence did nothing to change the status quo. No substantive minister for External Affairs and Commonwealth Relations was appointed. The Prime Minister, Alhaji Tafawa Balewa combined the functions of the minister of external affairs and commonwealth relations with that of his office. This order, however, changed when in 1961, a substantive minister for external affairs, Jaja Wachukwu was appointed, and that marked the effective take-off of Nigeria's Foreign Service [8]. Foreign missions quickly began to be established in many countries across the world. The young Nigerian government set up a Permanent Mission to the United Nations in New York, and elevated the status of the office of the Commissioner in London to that of a High Commission, while equally elevating the Nigerian Liaison office situated in Washington D.C to the status of an Embassy. Several other embassies and High Commissions were equally established, that by March 1961, Nigeria had set-up eleven diplomatic missions abroad [6]. The number rose to thirty-three (33) in 1963, forty-six in 1970 , ninety in 1982, ninety-seven in 1999, and two hundred and ninety in 2015. The number was nevertheless, trimmed down in 2016 by the President Buhari administration, to two hundred and nineteen [22]. Indicators are strong that there will be further reduction in the number of Nigeria's diplomatic missions by the Buhari administration. The reason is principally the bad state of the country's economy made worse by the steady fall in oil revenue and the rising dollar/naira exchange rate, to the pain of naira.

One rationale among many others for Nigeria's setting up of diplomatic relations with the rest of the world was, and remains, the huge importance placed on establishing and sustaining friendly relations with other sovereign states of the world by the government. The appreciation of Diplomatic mission lies on the fact that it aids communication and frequent interaction among the leaders of states and other principal figures in global politics. Hence, starting off diplomatic relations with others is seen by Nigeria as a vital tool for curtailing frictions in relations among states inter alia. Remarkably, Nigeria's diplomatic missions established overseas are broadly divided into two categories: the diplomatic and consular missions. High Commissions, Embassies, Permanent Delegations/Missions and Charges d'Affairs are classified under diplomatic missions and are subsequently located, in the capital cities of the host nations so as to ensure a close proximity to the Heads of States and Foreign Ministers of the host states, Nigerian Consulates and Area Offices all over the world are classified as Consular Missions. They can be established in other important industrial or commercial cities as authorized by the host governments and not essentially in the capital cities. Nigerian Overseas Mission are highly organized and is characyerized by their hierarchical structure which is subdivided into various sections or units in charge of specific duties in order to ensure effective and efficient performance of their duties by the mission. At the Head of the hierarchy of a Nigerian Mission, is a top personnel who can be designated as an Ambassador or High Commissioner. He/she is the chief representative of the government and people of Nigeria in their respective states of accreditation, and are in other words, responsible for the management of the affairs of the mission.

\section{Challenges of Nigeria's Diplomatic Mission}

Nigeria's diplomatic mission is challenged by among other things, problematic national interest. At the heart of diplomatic practice is the interest of a Nation. Diplomacy is therefore, mainly in relation to the defense and progression of the national interest of a State in a foreign land. As Akindele and Olusola pointed out, “[Nigeria's] Diplomatic mission is responsible for advancing and 
protecting the (Nigeria's) national interest in the host country" [4]. Every nation's diplomatic practice is or ought to be for the fulfillment of her national interest, but unfortunately, this vital 'National Interest' has often been disregarded with seemingly no defined place, clear and comprehensive goals for it in Nigeria's constitutions or in her diplomatic practices. Analysts and leaders alike differ on what makes up the national interest of Nigeria. Professor Osita Eze buttresses this assertion when he wrote, "It is difficult to identify Nigeria's conception of national interest since independence to date" [10]. More significantly, Gaya Best observed that the 1999 Constitution only supplied an extensive framework with no precise and clear direction regarding Nigeria's national interest at all [11]. And unfortunately, if clearly stating what the national interest of Nigeria has proved a difficult task so far, redefining it, in order to provide among other things, a detailed plan and the means to aid the quest of diplomacy in achieving its national objectives will even be more difficult due to mainly, the deepening of globalization and the surfacing of new influential players. However we look at this, this is an enormous challenge facing Nigeria's diplomatic practice in the $21^{\text {st }}$ Century. For Nigeria's diplomacy and diplomatic missions to be able to respond to global challenges in the $21^{\text {st }}$ Century, Best called for a clear definition and operationalization of the national interest of Nigeria [11].

One critical and decisive factor that makes for effective performance of diplomatic missions everywhere and lack of which haunts Nigeria's diplomatic mission is the adequacy of financial resources available for role performance. Funds allocated to foreign affairs have always been inadequate enough to ensure the anticipated service delivery [12]. The foreign affairs ministry is allocated just about a percent of the State budget for recurrent expenditure. There is a wide disparity when compared to the defence and some other ministries who receive far more. The depreciating exchange rate adjustment of the naira has only worsened the matter. Consequently, there has been upsetting news about the country's missions abroad owing rents and Nigerian diplomats being owed salaries and allowances. There have been so many embarrassments like difficulty in the timely payment of telephone and electricity bills [13]. Nigeria's Embassy office blocks in places like Khartoum, Teheran, and some others in Latin America were alleged to be submerged in leakages [14]. According to Faforawa "Our diplomatic missions continue to suffer needless and painful embarrassments arising from disconnection of utility services, ejection of staff from rented apartments, ejection of children from schools for failure to pay school fees and arrears of salaries of the diplomatic staff” ([12]: 3). This situation is debilitating to the Nigerian foreign missions' total productivity. With this avalanche of embarrassments, Nigerian diplomats in diplomatic mission will certainly be unable to pursue their diplomatic tasks with vigour, attention and effectiveness required of them. There is no gainsaying that for Nigeria's diplomatic missions to live up to its diplomatic responsibilities, and for Nigeria to play a more active part in global affairs, bigger fiscal outlay for foreign policy and diplomatic programmes is a sine-qua-non, for as Akinyemi puts it, “...active foreign policy and paltry budgetary allocation are mutually exclusive” [1]. The embarrassing situation stemming from inadequate financing of the foreign mission is further exacerbated by the shameful developments in some Nigerian embassies abroad where diplomats are compelled to embark on some sort of industrial actions having complained severally in vain over unpaid salaries. The most recent example of this form of problems faced by the country's embassies occurred on May 3, 2017 when the staff of the Nigerian Embassy in Washington D.C, United States, shut down activities at the Chancery in protest over unpaid salaries. The embarrassing event forced the permanent secretary of the Ministry of Foreign Affairs, Ambassador Sola Enikanolaiye, to direct the payment of three out of the five months the staff was being owed [15]. The anger of the staff in Washington almost got replicated by other consular staff in Atlanta and New York, who had not been paid for six months. Aside insufficient budgetary provision as a causal explanation for these developments, the problems is often compounded by acts of corruption replete in the Ministry of Foreign Affairs. Reports have it that sometimes the Federal Government made the funds available for the running of the embassies, but corruption by officials of the Foreign Affairs Ministry impedes the flow of the funds to the embassies. This way, the Foreign Affairs Ministry is fast squeezing the life out of the country's diplomatic missions abroad through diversion of and misuse of millions of dollars allocated to cover shortfalls in the embassies and consular offices.

Added to inadequate finance, paucity of training as a formidable challenge glares at the professional practices of Nigerian diplomats. This is mainly so, since diplomacy is a principled profession that warrants good training, sound academic background, and a concrete understanding of international affairs inter alia. It is evidently clear that a substantial number of Nigerian diplomats are seemingly not equipped with the vital training and orientation required to tackle the diplomatic challenges and realities of the present global age [13]. This is against the basis articulated in 1958 for the recruitment of the first batch of Nigerian diplomats by the Nigerian Prime Minister, Alhaji Tafawa Balewa, during a debate on foreign policy in the House of Representatives in Lagos:

After independence, Nigeria will largely be judged by the quality of the representation overseas, its diplomatic service. It is very easy to say that Nigeria should only be represented by the best, it is rather more difficult to define what the best is. In determining the qualifications for the new service, government has these considerations in mind: first, the candidate should be well educated, second, he must be or should be trained...([7]: 13).

This submission above contains an indication that then, the government placed a huge importance on the recruitment, training and development of staff to ensure a high caliber staff profile and performance in the foreign service, but reminiscing on his years as erstwhile foreign affairs minister, Ibrahim Gambari noted with regret that for long time since his employment into the Foreign Service by the Nigeria's Ministry of Foreign Affairs, that no further training was undertaken by the employees [16]. Though the Nigerian Foreign Service Academy was in the later years created, (in the early 1980s), it only attended to the training needs of staff freshly employed into the 
service. When once the recruited staff passed out, and deployed to their different areas of diplomatic service, hardly will further training, systematic programme for follow-up training and refresher courses for the officers be provided [17]. Consequently, in informed circles, the competence level of Nigerian diplomats is fast reducing and accounts for the stress which Nigerian foreign policy has been put into $[1,18]$. It is appalling that more than eighty percent of Nigeria's Foreign Service officers are unable to fluently speak an additional international language besides English [19]. In this era of complex negotiations and swift movement of individuals around the globe, it is imperative for Nigeria to step up and move away from a system of Foreign Service centered on generalists, to one more centered on specialists. Specialist disciplinary and language skills are vital. Decrying this un-supposed situation, Oyelakin, an ex-Ambassador, suggested that training should be given priority in the diplomatic profession [20]. The retired Diplomat actually recommended that the existing moribund Nigerian Foreign Service Academy should be upgraded to a degree and diploma awarding academy.

The above situation is worsened by the injection of non-professionals or political diplomats into the diplomatic profession. Diplomacy is such a serious business, in which there is no room for mediocrity [20]. Sad enough, and against the ethos of professionalism, the political loyalists are unjustifiably favoured to take over the ambassadorial job of professional diplomats, who have been on the waiting line of succession for the past 30 to 35 years to reach the pinnacle of their chosen profession, and to be appointed ambassadors of their country. The demobilization of highly qualified diplomats and mobilization of non-career, inexperienced political nominees send wrong signals of contradiction, confusion and complication. In the words of a retired Nigerian Ambassador, Oladapo Fafowara,

...some of Nigeria's diplomatic missions were opened to accommodate failed politicians and hacks who demand diplomatic postings as compensations from the government...Many of them go abroad to serve themselves and not the nation...when I served in Ankara, Turkey, in 1975, with concurrent accreditation to Iran, I could not understand the reason for having our diplomatic mission in Ankara at the time. Subsequently, I learnt that the two missions were opened to accommodate Brigadier Kurubo...I discovered that Kurubo was not even known in the Foreign Ministry...([14]:3)

Writing in 2016, Abdulwahab notes that “...about 85 seasoned career diplomats have been unjustly rendered redundant and pushed aside in favour of non-career political ambassadors" [21]. One danger in this is the withering away of morale on the part of the professional diplomats who see 'outsiders' occupying posts to which they aspire. Such a weakening of morale resulting from having political appointees, rather than career diplomats to head diplomatic missions overseas, have injected bad blood and some sort of cold war into the practices of Nigeria's diplomatic missions. In his blame of the Nigerian politicians for the failure of the Nigerian diplomatic mission to live up to its diplomatic responsibilities, Abdulwahab asks “....why can’t Nigeria appoint non-career pilots to fly presidential planes? Or non-career medical doctors to manage our hospitals?” [21] It remains indubitable that politicians have in no small measure contributed to the decimation of Nigeria's diplomatic service. Hardly can a difference be spotted between textbook diplomacy and functional diplomacy or between nominal and practicing ambassadors in Nigeria. For show of political favours, fine extraordinary diplomats who have been trained, tested and trusted in the strategic diplomatic business for over three decades in both bilateral and multilateral diplomatic environment, become supplanted with ordinary citizens who are either relations or political friends of those in power. In Nigeria, the foreign missions have thus become dumping grounds serving as quid pro quo for transacted political patronage [22]. Appointments to all-important ambassadorial offices of the country and other foreign mission posts, simply expresses the leverage of the self-serving political actors to circumvent institutional protocols to safeguard the integrity of the recruitment process and the expected credibility of the Foreign Affairs Ministry. Lacking the requisite experience and qualification needed for the offices, these political ambassadors arrive in the Ministry of Foreign Affairs with intellectual deficiencies and mere notes of introduction as cousins and nieces of the big names in the political registrar of the sitting administration. It is scarcely a surprise that what we notice in many of Nigeria's foreign missions is "kabu-kabu" and "Area-boy" diplomacy. This is a diplomatic disaster, nothing else, nothing less. It has regrettably become fashionable for Nigerians who are desirous of becoming ambassadors to simply join politics instead of joining the diplomatic service. By becoming loyal sycophants to a political leader, they will end up not just as ambassadors, but ambassadors posted to plum and juicy missions. It cannot be denied however, that Nigeria's Foreign Service has had in the past, some non-careerists who performed creditably well. Some of them were patriotic and honest Nigerians who had done many great things for the country. They brought various experiences of academic excellence, maturity, intelligence into the Foreign Service. While those were very successful, many others did not, either because they were not ambassadorial materials or they were foreign bodies in the Foreign Service, who were probably more interested in the aura of elegance of the ambassadorial post, the exotic social life and the coveted title than in the real needs and demands of the job.

One problem which reduces the morale of the Nigerian mission as a whole and that of the commercial attaché in particular, is the problem of status and rift between political representation and commercial representation. Because the occupant of the position of commercial attaché is usually on loan to the mission for a fixed number of years, and looks up to his home ministry for his career prospects, he feels therefore, from the outset, that he is not a member of the regular staff, and acts it out. This injects some sense of feelings of alienation, which is inimical to the expected team spirit required for an overall effective performance of the Nigerian overseas missions. From this, some level of bad blood has developed between the professional diplomats and the commercial attaché with a growing tendency for the professional diplomats to view the attaché as usurper of the investigative and 
reportorial functions which he normally guards with jealous tenacity. What appears more demoralizing to the commercial attaché is that, irrespective of his seniority or rank in the public service, he has to send his reports or dispatches to the Head of Mission through a Third or Second Secretary, an officer several years his junior. Closely related to this problem is the hard fact that mindless of the commercial attaché's rank in the public service, he/she is, in terms of diplomatic protocol, very low down the diplomatic list. This low status, Olatunde argues, does not enhance opportunities for more and better contacts in the field [23]. Related to this, is the jurisdictional problems inherent in the divided system of representation. For instance, the appointments of commercial attachés are made in consultation with the Foreign Affairs Ministry. Neither the Foreign Affairs Ministry nor the Ministry of Commerce is particularly satisfied with the arrangement [24]. Each of the ministries wants to have the sole authority in appointments. The position of the Foreign Affairs Ministry on this reflects the traditional belief in the primacy of politics over economics in international relations. The Foreign Affairs Ministry will want an attaché to be sent to a mission of their choice, and the Commerce Ministry will want otherwise.

It is inevitable at this point to advance the argument that the application of quota to Nigerian diplomatic service has been producing unhelpful objectives. The principle of federal character adopted in the appointment of individuals in important positions in Nigeria's diplomatic service has evidently dented the principles of merit, talent and competence. Evidently, the constitutional demands for the reflection of federal character and fair regional representation in the selection and nomination of public officers, has equally affected the diplomatic mission drastically. This can be blamed on the manipulation of the recruitment process rather than the possibility of wellequipped candidates across the different states of the federation. The current recruitment arrangement which has seen the influx of a significant number of underqualified personnel into the specialized unit of the Foreign Service, merely justifies the abuse of the federal character arrangement for conscription into the Foreign Service. As a result, people with confirmed ability for high standard performance, insightful thinking, ingenious solutions and sound practical approaches to policy formulation and implementation are overlooked in appointments and promotions. This way, averageness and incompetence are thoughtlessly rewarded, while misconduct and unethical conducts flourish beneath a culture of favouritism, impunity and severe laxity. Although intended to lubricate Nigerian federalism for effective functioning, it must be admitted that the federal character principle does have some negative consequences for the diplomatic service. Recruitments into the foreign affairs ministry and diplomatic appointments follow the pattern of equal number from each state. This has translated especially in the years of the previous republics, into the recruitment of far larger numbers than required and what could be absorbed into the system. The financial implication of this is enormous, especially with the current challenging financial situation of the country where oil revenue is falling steadily and the economy declining fast. This has necessitated suggestions to the present Buhari administration to cut down cost by closing some Nigeria's diplomatic missions abroad. The frightening predicament attributable to this proposed shutting down touted around is that "When we close mission, we damage relations that we have taken years to build" [25]. The federal character experience so far has shown that it is applied at the point of entry, and at the level of career progression into the ambassadorial rank. A situation in which a junior officer has gone on ambassadorial posting and back, while his seniors on higher salary scale still pray for their turn to come, simply because they come from top heavy state, is not helpful for the growth of Nigerian Foreign Service. There is therefore, imperative for a reconsideration of the federal character principle as it applies to Nigeria's diplomatic mission, to encourage productivity in the discharge of diplomatic assignments.

Another hurdle facing Nigeria's diplomatic missions is the oft misunderstanding between the diplomatic missions and the headquarters. Whereas the headquarters in Nigeria is mostly accountable for the articulation and making of policies, headquarters virtually count on their missions to follow through with their instructions. Nevertheless, officials at missions are more often than not accused of assuming and claiming superior knowledge of the difficulties on ground, particularly as it entails their country or organization of accreditation, which occasionally makes them reluctant of implementing the directives from the headquarters [11]. Enikanolaye, the previous Charge d'Affairs, Nigeria's High Commission in India and permanent secretary, Ministry of Foreign Affairs, brought to mind of when cases like basic human rights, refugees etc., were deemed not "so relevant” but more or less as mundane cases of Nigeria's international relations, as against decolonization and anti-apartheid; then he was derided and viewed as whiling away time with 'mundane' issues, and thus, dealing with irrelevancies. The diplomats' error was dealing with human rights questions as the then Third Secretary at the United Nations Department. The repercussion was that he was not seen as working in tune with Nigeria's policy making and thus irrelevant to the nation's policy.

Nigeria's diplomacy is not citizen-centered. This is a challenge that daunts Nigeria's diplomatic performance. Citizen diplomacy is a principle in accord with the constitutional outlay that applies to making the interest of the Nigerian citizens, both within Nigeria and elsewhere a priority. But contrary to this principle, Nigerians' rights, dignity and privileges, especially in the overseas, have remained unprotected and undefended, as the apparent criminalization of Nigerians abroad has assumed a worrisome dimension. The notion thereby imprinted in the mindsets of Nigerians, particularly those in the diaspora, is that the Nigerian state and its embassies abroad are not bothered about the predicaments faced by its citizens in the diaspora [26]. The missions have not really adjusted their activities to accord due recognition to citizens. Inadequate attention is paid to many Nigerian nationals. Incidents involving Nigerians living in the diaspora, would have meliorated if the Nigerian state interfered through the diplomatic missions, were left unattended. Counseling and legal services are hardly available for the multitude of Nigerians who now travel abroad to make a meaningful living [1]. Consequently, Nigerians abroad are 
seen as sheep without shepherds. It is doubtful if anyone will be convinced about Nigeria's relevance when her citizens are being given criminal treatment in major capitals of the world, while the country's embassies and high commissions, are toeing the line instead of pressing innocence as vigorously as possible until a court of competent jurisdiction decides otherwise. Nigeria's diplomatic operation is such that does not carry the people along. The average Nigerian is ignorant of how the country's diplomacy operates and how it is conducted. There appear to be no feeling of involvement of the citizens at home, despite being stated clearly in the constitution that supreme power belongs to the people who after all, empowers the government.

We make haste to add that apparent uphill task that Nigeria's diplomatic mission faces is failure in penetrating the political and social structures in their countries of accreditation. Without penetration, there can be no successful outings. There are interests and individuals outside the diplomatic circles whose support and influence an ambassador must cultivate and nurture. From the experience of Nigeria's diplomatic practice, the country has not been penetrating the host countries [1], while in Nigeria, other countries' foreign missions can reach any person and group in the country which is crucial for their effective representation. Nigerian diplomats' impenetrability of their host countries has a link with inadequate funding. As Saliu notes, Nigeria's diplomatic missions cannot organize frequent dinners, luncheons, presentation of gifts and discharge functions that can easily break down social and political barriers, due essentially to poor funding [1]. The mentioned activities may be cost-consuming, but certainly can achieve more than what formal channels can achieve. A lot of issues in diplomatic practice can be resolved through behind-the-scene maneuverings which have become the hallmarks of modern diplomacy [1].

The diplomatic performance of every nation is but an amplification of their local realities. This lends credence to the main thesis of the linkage school that the domestic environment is not an island that is totally unconnected to the external environment of a state. "An erupting issue in the domestic environment can and should be impacted upon by the external environment and vice versa, either positively or negatively, depending on how the country does her permutations" ([5]:175). A country where there is a dynamic policy thriving internally, will easily map out a similar spirited foreign policy overseas. Ashiru observes that "conversely, the Nigerian Foreign Service can only project what the government at home represents as you cannot sow corn and reap tomato" [27]. Succinctly put therefore, the problems and weaknesses inherent in Nigeria's foreign service and diplomatic performance today, owes to the dysfunctional character of the Nigerian state, her weak and globally marginalized economic status, bad governance etc. A weak state begets weak diplomacy. "No nation that is weak at home, politically or economically can be strong abroad" ([28]:112). Diplomatic success and effectiveness is a function of home strength. Nigeria is unarguably a weak state, with attendant indices that define her so (see [28,29,30,31]). A number of issues that challenge the Nigerian state and society such as long absence of democracy, corruption, bad governance, terrorism etc, have taken diplomatic weight from Nigeria's voice at the international level. The loss of Nigeria in the African Development Bank's presidency in 1995 and 2005 and the exclusion of the country from the G20 and her backstage role in the Tony Blair Commission for Africa are clear indications of the failure of diplomacy and by extension, the country's Foreign

\section{Conclusion}

The government of the day should deliberately select the suitable dramatis personae that will effectively pull the strings at the Ministry of Foreign Affairs and its diplomatic missions in the diaspora. In nominating or appointing the above mentioned officials, the paramount determinant should be merit. Diplomacy is a serious business in which there is no room for mediocrity. Especially in the $21^{\text {st }}$ century, the practice of diplomacy has changed due to revolution in information communication technology, and other phenomenal factors. Therefore, non-career appointees based on experience outside of the diplomatic circle cannot understand and appreciably fit into the modern-time ambassadorial roles, demands and challenges. The short time training that precedes the deployment of the non-careerists is grossly inadequate for the task of the office. It is both imperative and compelling therefore, for the Executive Government of Nigeria to withdraw the long list of serving and nominated non-career ambassadors from Nigeria's Foreign Service. This way, Nigeria's diplomatic mission will be on a right and fast lane towards living up to its diplomatic responsibilities. It is recommended that those career diplomats whose position and ranks have been affected by the infusion of political functionaries into the diplomatic service, should be conferred with the title 'Ambassador-in-situ' to compensate their feelings of frustration, and to appreciate their long and loyal service to the nation. Besides making sure that the overseas missions are manned by capable officers, instructional programmes ought to be reevaluated so as to provide diplomats with the required expertise for effective performance. One crucial recommendation is that the application of the federal character principle, if at all will apply, should be limited to the point of entry into the service for career diplomats so as to solve the lingering problem of frustration and lowering of morale among the staff.

\section{References}

[1] Saliu, Hassan (2012) “The Politics of Diplomatic Appointments in Nigeria”, In Imobighe Thomas and Alli Warisu (Eds.) Perspectives on Nigeria's National Politics and External Relations. Ibadan: University Press.

[2] Boma, L., Terfa. T. and Tsegwu. S, (2015) Nigeria Foreign Policy and Global Image: A Critical Assessment of Goodluck Jonathan’s Administration, Journal of Mass Communication and Journalism, 5 (2).

[3] Beridge, G. R (2010) Diplomacy: Theory and Practice. London: Palgrave Macmillan.

[4] Adeniji, Olu. (1990). "Implementation and Administration of Foreign Policy: A Note on the Relationship Between the Ministry of External Affairs and the Nigerian Missions Abroad”, In 
Akindele R.A and Olusanya Gabriel (Eds.) The Structure and Processes of Foreign Policy Making and Implementation in Nigeria, 1960-1990, Lagos: Nigerian Institute of International Affairs.

[5] Saliu, Hassan (2013) "New Options for Nigerian Foreign Policy", Nigerian Journal of International Studies, 38 (2).

[6] Aremu, Johnson (2016) Structure and Challenges of Nigeria's Overseas Diplomatic Missions, European Scientific Journal, 12 (11), 525-538.

[7] Jolaoso, Olujimi (1991) In the Shadows: Recollections of a Pioneer Diplomat. Lagos: Malthouse Press.

[8] Gambari Ibrahim. (1980). Party Politics and Foreign Policy: Nigeria Under the First Republic, Zaria: Ahmadu Bello University Press.

[9] Opera, G (2016) “Reduction in Diplomatic Mission”, National Mirror, 2 February 2016.

[10] Eze, Osita. (2010). Citizen Diplomacy. Lagos: Nigerian Institute of International Affairs

[11] This Day (2016) “Nigeria's Foreign Policy and Strategy: the Challenges of Domestic and Global Dynamics", December 11, 2016.

[12] Fafowora, Oladapo. (2015). "Proposals for Reduction of Diplomatic Missions” The Nation, September 24, 2015.

[13] Enuka, Chuka and Ojukwu, Emmanuel (2016) “Challenges of Nigeria's Foreign Policy” International Journal of Arts and Humanities, Ethiopia, 5 (2).

[14] Mustapha, Abdul (2008) “Challenges of Nigeria’s Foreign Policy in the Post-Cold War Era”, In Adebajo Adekeye and Mustapha Abdul (Eds.), Gulliver's Troubles: Nigeria's Foreign Policy After the Cold War, Scottsville: University of KwaZulu-Natal Press.

[15] Sahara Reporters (2017) How Corruption in Foreign Affairs Ministry is Killing Nigerian Diplomatic Missions Abroad, Sahara Reporters, May 6, 2017. Available at: http://saharareporters.com/2017/05/06/how-corruption-foreignaffairs-ministry-killing-nigerian-diplomatic-missions-abroad.

[16] Gambari Ibrahim. (1989). “Nigeria's Foreign Policy at Cross Roads: Concepts, Critical Issues and Management of External Affairs under the Buhari Administration”, In Akinyemi A. B, Agbi, S.O and Otubanjo, A.O (Eds.) Nigeria Since Independence: The First 25 Years, Ibadan: Heinemann.

[17] Chibundu, V.N. (2009) Foreign Policy with Particular Reference to Nigeria, 1961-2008, Ibadan: Spectrum Books Limited.
[18] Abati, R (2011) “The Ambassador Who Failed Anthem Test”, The Guardian, March 18, 2011.

[19] Fafowora, Oladapo (2008) "The Unsung Player: The Nigerian Diplomat and the Foreign Service”, In Adekeye Adebajo and Mustapha Abdul (2008) Gulliver's Troubles: Nigeria's Foreign Policy after the Cold War, Scottsville: University of KwaZuluNatal Press.

[20] Oyelakin, Oladejo (2014) The Nigerian Diplomatic Practice. Lagos: Nigerian Institute of International Affairs.

[21] Abdulwahab A (2016) "How Politicians Destroy Nigeria's Diplomatic Service” This Day Newspaper, 24 November, 2016.

[22] Araoye, Ademola (2017) "A Dearth of Diplomacy and the Decay of the Nigerian Diplomat” The News, $17^{\text {th }}$ October, 2017.

[23] Ojo, Olatunde. (1990). "Commercial Representation in Nigeria's Overseas Missions: Its Nature, Functions and Problems”, In Akindele R.A and Olusanya Gabriel (Eds.) The Structure and Processes of Foreign Policy Making and Implementation in Nigeria, 1960-1990, Lagos: Nigerian Institute of International Affairs.

[24] Akindele, R. A and Olusola Segun. (1990). "Embassy of Nigeria in Ethiopia: Structure and Process for Foreign Service Role Performance", In Akindele R.A and Olusanya Gabriel (Eds.) The Structure and Processes of Foreign Policy Making and Implementation in Nigeria, 1960-1990, Lagos: Nigerian Institute of International Affairs.

[25] Ashiru, Olugbenga. (2013). "Nigeria’s Foreign Policy in a Changing World” Punch Newspaper, August 15, 2013. Available at: www.punchng.com/opinion/nigeria-foreign-policy-in-a-changingworld-3.

[26] Eze, Osita. (2009). "Interrogating the National Interest in Nigeria’s Foreign Policy”, In Eze Osita (Ed.) Beyond 50 Years of Nigeria's Foreign Policy: Issues, Challenges and Prospects, Lagos: Nigerian Institute of International Affairs.

[27] Ashiru, Olugbenga. (2009). "Nigeria: Professionalism and Foreign Service”, This Day Newspaper, January 19, 2009.

[28] Alli, Warrisu. (2013). "Nigeria: State Weakness and Foreign Policy” Nigerian Journal of International Studies, 38 (2).

[29] Rotberg, Robert. (2003). State Failure and State Weakness in Time of Terror, Washington D.C: Brooking Press.

[30] Rotberg, Robert. (2004). When States Fail: Causes and Consequences. Princeton: Princeton University Press.

[31] Akude, J. E. (2007). The Failure and Collapse of the African State on the Example of Nigeria, Madrid, FRIDE.

(C) The Author(s) 2020. This article is an open access article distributed under the terms and conditions of the Creative Commons Attribution (CC BY) license (http://creativecommons.org/licenses/by/4.0/). 